\title{
Comparison of the retention rates of thiamin, riboflavin, and niacin between normal and high-oleic peanuts after roasting
}

\author{
Da-Som Kim ${ }^{1} \cdot$ Hoe Sung Kim ${ }^{1}$ Seong Jun Hong ${ }^{1}$.

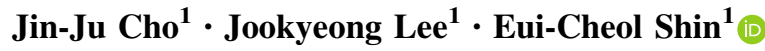

Received: 19 May 2018/ Accepted: 11 June 2018/Published online: 15 June 2018

(C) The Korean Society for Applied Biological Chemistry 2018

\begin{abstract}
This study investigated the amounts of thiamin, riboflavin, and niacin in normal and high-oleic peanuts and compared the retention rates after roasting via HPLC analysis. Method validation showed a high linearity $\left(r^{2}>0.99\right)$, and the limits of detection and quantification were $0.001-0.038$ and $0.002-0.115 \mu \mathrm{g} / \mathrm{mL}$, respectively. Accuracy and precision were confirmed using standard reference materials. Thiamin content was not significantly different between the normal and high-oleic cultivars; however, it significantly decreased in the roasted peanut cultivars. Although there were no significant differences in riboflavin between the cultivars, a significantly increased amount of riboflavin was observed in the roasted peanuts, which confirms that riboflavin is highly stable to thermal treatment such as roasting. With only a small difference between the cultivars, niacin showed a decreased retention rate with roasting in normal cultivars, but a significantly increased retention rate with roasting in high-oleic cultivars. The amount of thiamin, riboflavin, and niacin present in peanuts and their retention rates after roasting showed variations among the cultivars. This study provides basic data on the water-soluble vitamins in raw and roasted peanuts.
\end{abstract}

Keywords High-oleic peanuts $\cdot$ Niacin $\cdot$ Retention rate Riboflavin · Thiamin

Eui-Cheol Shin

eshin@gntech.ac.kr

1 Department of Food Science, Gyeongnam National University of Science and Technology, Jinju, Gyeongnam 52725, Republic of Korea

\section{Introduction}

The peanut, a nutritionally high-value legume, has been widely utilized as a food material since 950 B.C. in South America [1]. The cultivation and research of peanuts has continuously advanced, and a myriad of studies have focused on increasing its production, product quality, and developing cultivars that are highly resistant to insects [2]. Consumption of peanuts leads to reduced body weight, attenuated blood pressure, and decreased serum cholesterol [3]. In general, normal peanuts are composed of $50 \%$ fatsoluble components, $25 \%$ proteins, and various water-soluble vitamins. Peanuts include a variety of fat-soluble fatty acids, primarily oleic acid (55\%) and linoleic acid (25\%). High-oleic cultivars, containing more than $80 \%$ oleic acid and less than 5\% linoleic acid, have been developed through breeding improvements since the 1980s [4-6]. According to the literature, two genes, $a h F A D 2 A$ and $a h F A D 2 B$, were identified that are relevant to the proportion of oleic acid in peanuts. High activation of these two genes increased the fatty acid composition of normal cultivars, while low activation resulted in cultivars with a high proportion of oleic acid (> 80\%) [7-9]. In South Korea, our research team investigated the fat-soluble nutrients and oxidative stability of high-oleic peanuts as compared with normal cultivars [10]. Another study compared the antioxidant activities based on the amount of polyphenol compounds and sensory characteristics between high-oleic peanuts and normal cultivars [11].

Vitamins, the trace nutrients present in foods and food materials, are essential for higher animals to survive, and need to be ingested through food, as only minimal-to-no vitamins are synthesized in the body [12]. Vitamins are categorized into fat- and water-soluble vitamins. Among 
the water-soluble vitamins, thiamin (vitamin $\mathrm{B}_{1}$ ) was discovered first. Thiamin regulates in vivo enzyme activities and plays paramount roles in carbohydrate metabolism. It is also known to stimulate appetite and digestion and is involved in neuromodulatory functions [13]. Riboflavin (vitamin $\mathrm{B}_{2}$ ) is involved in growth promotion, oral mucosal protection, and in vivo oxidation and reduction. Riboflavin deficiency can cause stunted growth in children, stomatitis, glossitis, and angular stomatitis [14]. Niacin (vitamin $\mathrm{B}_{3}$ ) governs the oxidation and reduction of nutrients, dilates peripheral blood vessels to promote blood circulation, and reduces cholesterol levels in the body. When scarce, however, it can cause pellagra, black tongue disease, and dermal and mucosal damage [15]. Although studies have reported on the functional properties of the vitamins, only a few of them have investigated the stability of the vitamins in a variety of complex food matrices. The prediction of changes in stability induced by different chemical forms is known to be difficult [12]. Thiamin is not thermally stable, having a low retention rate at $100{ }^{\circ} \mathrm{C}$ and higher temperatures. Riboflavin is oxidatively and thermally stable but can easily be devitaminized under alkali conditions and UV exposure. Niacin exhibits relatively superior thermal stability compared with vitamins thiamin and riboflavin, but shows a high affinity for hydrolysis in acid and alkali solutions [16]. To this end, the processing methods to maintain the stability of water-soluble vitamins in foods and food materials need investigation, and studies have investigated methods to increase the retention rate of water-soluble vitamins by applying a minimal amount of cooking water and reduced heating time [17]. Additionally, studies comparing nutrient compositions in peanuts between normal cultivars and high-oleic cultivars have mainly focused on fat-soluble components and the related aroma and flavor components, but only a handful of studies have compared the amounts of water-soluble vitamins [18-20]. A previous study by our research team [21] also compared the amount of a fat-soluble vitamin of peanuts, tocopherol, in normal and high-oleic cultivars, and the result showed that normal cultivars contained higher tocopherol levels than high-oleic cultivars.

Therefore, the objective of this study was to investigate the amounts of thiamin, riboflavin, and niacin in normal and high-oleic peanut cultivars, and examine the retention rates of the vitamins after roasting, a conventional peanut processing method.

\section{Materials and methods}

\section{Materials}

The normal cultivars used in this study, Daekwang and Poongan, and high-oleic cultivars, $\mathrm{K}-\mathrm{Ol}$ and Milyang\#14, were provided by the National Institute of Crop Science at the Rural Development Administration (Milyang, Gyeongnam, Republic of Korea). All peanut samples were cultivated from 2016 to 2017 and were provided fresh. The samples were vacuum-packaged upon arrival to prevent acidification and stored at $-20{ }^{\circ} \mathrm{C}$ until analysis. Thiamine hydrochloride; riboflavin- $5^{\prime}$-adenosine diphosphate (FAD), riboflavin-5'-phosphate (FMN), and riboflavin; and nicotinic acid and nicotinamide, were purchased from Sigma-Aldrich Co. (St. Louis, MO, USA) and used as standards for vitamin $\mathrm{B}_{1}, \mathrm{~B}_{2}$, and $\mathrm{B}_{3}$ analysis, respectively. All other chemicals used in the study were analytical grade and purchased from Sigma-Aldrich Co.

\section{Extraction and pretreatment}

To extract vitamins thiamin and niacin from peanuts, a method outlined by Kim et al. [22] was used. Briefly, $25 \mathrm{~mL}$ of a $5 \mathrm{mM}$ sodium 1-hexanesulfonate solution was added to $5 \mathrm{~g}$ of homogenized sample and extracted by a sonicator (8510E-DTH, Branson, Danbury, CT, USA) at $40{ }^{\circ} \mathrm{C}$ for $30 \mathrm{~min}$, followed by centrifugation of the extracts at 15,000 rpm for 10 min (Smart 15, Hanil, Seoul, Republic of Korea). The supernatant was then passed through a $0.45-\mu \mathrm{m}$ syringe filter for water-soluble solvents (Whatman Inc., Maidstone, UK). To extract vitamin $\mathrm{B}_{2}$ from peanuts, a method by Kim et al. [22] and a vitamin analysis method by Food Codex 1.2.2.3 [23] were utilized. That is, $5 \mathrm{~g}$ of a homogenized sample was dissolved in $50 \mathrm{~mL}$ distilled water and a reflux extraction method was then applied in an $80{ }^{\circ} \mathrm{C}$ water bath (SH-502, Seyoung Co., Incheon, Republic of Korea) for $30 \mathrm{~min}$. The extracts underwent a first filtration through a Whatman No. 1 filter paper (Whatman, Amersham, UK) and then a second filtration with a $0.45-\mu \mathrm{m}$ syringe filter for water-soluble solvents.

\section{HPLC analysis}

To determine the amounts of thiamin and niacin in raw and roasted peanuts, an Agilent 1100 infinity HPLC with a diode array detector (Agilent Co., Wilmington, DE, USA) was used. The column used for separation was a YMCPack ODS AM $(250 \times 4.6 \mathrm{~mm}, 5 \mu \mathrm{m})$ and used at $40{ }^{\circ} \mathrm{C}$. The wavelength of the detector was set to $270 \mathrm{~nm}$. The mobile phase for solvent A was a mixture of $7.5 \mathrm{~mL}$ acetic 
acid, $0.2 \mathrm{~mL}$ triethylamine, and $5 \mathrm{mM}$ sodium 1-hexanesulfonate and solvent B was methanol (solvent B), and the analysis was carried out under a linear gradient elution. The flow rate of the mobile phase was set to $0.8 \mathrm{~mL} / \mathrm{min}$, and the mobile phase was varied as follows: $0 \mathrm{~min}: 100 \%$ solvent A, 8 min: $100 \%$ solvent A, 20 min: $75 \%$ solvent A, 30 min: $55 \%$ solvent A, 31 min: $100 \%$ solvent A, 45 min: $100 \%$ solvent A (Table 1). An Agilent 1100 HPLC system (Agilent Co.) with a fluorometric detector was utilized to determine the amount of vitamin $\mathrm{B}_{2}$. The analytical column used for separation was a YMC-Pack Pro RS $\mathrm{C}_{18}$ $(250 \times 4.6 \mathrm{~mm}, 5 \mu \mathrm{m}$, YMC, Seongnam, Republic of Korea) and used at $40{ }^{\circ} \mathrm{C}$. The wavelengths of the detector were set to $445 \mathrm{~nm}$ for excitation and $530 \mathrm{~nm}$ for emission. The mobile phase was prepared with $10 \mathrm{mM} \mathrm{NaH}{ }_{2} \mathrm{PO}_{4}(\mathrm{pH}$ 5.5) and methanol (75:25, v/v), and the analysis was conducted at a flow rate of $0.8 \mathrm{~mL} / \mathrm{min}$ under isocratic elution conditions (Table 1) [23].

\section{Calculation of vitamin amount}

Utilizing the standards, the vitamin amounts were calculated using the formula below.

Vitamin amount $(\mathrm{mg} / 100 \mathrm{~g})=\frac{S \times a \times b}{\text { sample weight }(\mathrm{g})} \times \frac{100}{1000}$

where $S$ concentration of the extracted solution standards $(\mu \mathrm{g} / \mathrm{mL}), a$ total volume of the extracted solution $(\mathrm{mL})$, and $b$ dilution factor of the extracted solution.

\section{Limit of detection (LOD) and limit of quantification (LOQ)}

Using the calibration curves of the standard reference materials for thiamin, riboflavin, and niacin, the LOD and LOQ were calculated using the equations below [24]:

$\mathrm{LOD}=3.3 \times \delta / S$

$\mathrm{LOQ}=10 \times \delta / S$

where $\delta$ is the standard deviation of the $Y$-intercept of the standard curve and $S$ is the mean of the slope.

\section{Method validation of thiamin, riboflavin, and niacin using the standard reference materials}

To validate the methods for thiamin, riboflavin, and niacin analysis, the standard reference materials (SRM) 1849a (Infant/adult nutritional formula) and SRM 2387 (peanut butter) were purchased from NIST (National Institute of Standards and Technology, Gaithersburg, MD, USA).

\section{Statistical analysis}

The amounts of the water-soluble vitamins thiamin, riboflavin, and niacin were analyzed using an SAS 9.1 (Statistical Analysis System, SAS Institute Inc., Cary, NC, USA). A paired $t$ test $(P<0.05)$ was used to determine significance.

Table 1 HPLC operating condition for vitamin thiamin, riboflavin, and niacin analyses

\begin{tabular}{|c|c|c|}
\hline & Thiamin and Niacin & Riboflavin \\
\hline Instrument & Agilent 1100 series & Agilent 1100 series \\
\hline Column & YMC-Pack ODS AM $(250 \mathrm{~mm} \times 4.6 \mathrm{~mm}, 5 \mu \mathrm{m})$ & $\begin{array}{l}\text { YMC PRO RS C18 }(250 \mathrm{~mm} \times 4.6 \mathrm{~mm} \text {, } \\
5 \mu \mathrm{m})\end{array}$ \\
\hline Column temp. & $40^{\circ} \mathrm{C}$ & $40^{\circ} \mathrm{C}$ \\
\hline Detector & Diode array detector $(270 \mathrm{~nm})$ & FLD $(E x=445 \mathrm{~nm}, \mathrm{Em}=530 \mathrm{~nm})$ \\
\hline Flow rate & $0.8 \mathrm{~mL} / \mathrm{min}$ & $0.8 \mathrm{~mL} / \mathrm{min}$ \\
\hline Mobile phase & $\begin{array}{l}\text { A: } 5 \mathrm{mM} \text { sodium 1-hexanesulfonate (acetic acid } 7.5 \mathrm{~mL}+\text { triethylamine } \\
0.2 \mathrm{~mL} / 1 \mathrm{~L} \text { ) } \\
\text { B: } 100 \% \mathrm{MeOH}\end{array}$ & $\begin{array}{l}10 \mathrm{mM} \mathrm{NaH}{ }_{2} \mathrm{PO}_{4}(\mathrm{pH} 5.5): \mathrm{MeOH}=75: 25 \\
\quad(\mathrm{v} / \mathrm{v})\end{array}$ \\
\hline $\begin{array}{r}\text { Gradient } \\
\text { profile }\end{array}$ & $\begin{array}{l}0 \text { min: A } 100 \% \\
8 \text { min: A } 100 \% \\
20 \text { min: A } 75 \%+\text { B } 25 \% \\
30 \mathrm{~min}: \text { A } 55 \%+\text { B } 45 \% \\
31 \text { min: A } 100 \% \\
45 \text { min: A } 100 \%\end{array}$ & Isocratic \\
\hline $\begin{array}{l}\text { Injection } \\
\text { volume }\end{array}$ & $20 \mu \mathrm{L}$ & $20 \mu \mathrm{L}$ \\
\hline
\end{tabular}




\section{Results and discussion}

\section{Method validation}

The analysis of thiamin, riboflavin, and niacin in peanut cultivars was validated via linearity, LOD, and LOQ using SRM. The results are shown in Table 2. Thiamin, riboflavin, and niacin all exhibited $r^{2}$ values of 0.991-0.999, indicating high linearity. The LOD showed the highest value for vitamin thiamin with $0.038 \mu \mathrm{g} / \mathrm{mL}$, followed by 0.019 and $0.008 \mu \mathrm{g} / \mathrm{mL}$ for the nicotinic acid and nicotinamide forms of niacin, respectively. Riboflavin as analyzed by the fluorometric detector demonstrated a lower LOD value (FAD, $0.004 \mu \mathrm{g} / \mathrm{mL}$; FMN, $0.001 \mu \mathrm{g} / \mathrm{mL}$; riboflavin, $0.001 \mu \mathrm{g} / \mathrm{mL}$ ) than thiamin and niacin as analyzed by the UV detector. Like the LOD, the LOQ exhibited the highest value for thiamin with $0.115 \mu \mathrm{g} / \mathrm{mL}$, followed by 0.056 and $0.025 \mu \mathrm{g} / \mathrm{mL}$ for the nicotinic acid and nicotinamide forms of niacin, respectively. Riboflavin analyzed by FLD showed lower LOQ values (FAD, $0.013 \mu \mathrm{g} / \mathrm{mL}$; FMN, $0.002 \mu \mathrm{g} / \mathrm{mL}$; riboflavin, $0.002 \mu \mathrm{g} /$ $\mathrm{mL}$ ) than vitamins thiamin and niacin analyzed by the UV detector. A previous study analyzing the LOD of watersoluble vitamins in baby milk using HPLC reported less than $0.1 \mu \mathrm{g} / \mathrm{mL}$ for thiamin and less than $0.05 \mu \mathrm{g} / \mathrm{mL}$ for riboflavin and niacin [25]. Kim et al. [26] also found a
LOD of $0.011 \mu \mathrm{g} / \mathrm{mL}$ for thiamin, $0.014 \mu \mathrm{g} / \mathrm{mL}$ for riboflavin, $0.044 \mu \mathrm{g} / \mathrm{mL}$ for nicotinic acid, and $0.024 \mu \mathrm{g} / \mathrm{mL}$ for nicotinamide. Based on the results from the previous studies, the LOD ranges of the present study are reasonable, confirming the validity of our analysis of thiamin, riboflavin, and niacin in peanut cultivars.

Accuracy and repeatability of the analysis were examined using SRM, and the results are described in Table 3. The ranges of analytical values were within with the ranges certified by NIST. Bias values, the difference between the certified values and analytical values, were very small (0.07 for thiamin, 0.09 for riboflavin, and 1.20 for niacin). The relative standard deviation (\%RSDr) was below $10 \%$, and the $Z$ value, which indicates significance when absolute values are within \pm 2 , was $-1.4,1.8$, and 1.2 in vitamins thiamin, riboflavin, and niacin, respectively, confirming the reliability of the analysis.

\section{Thiamin}

The amounts of thiamin in normal peanuts and high-oleic peanuts, as well as changes in retention rates after roasting, were investigated. The results are shown in Fig. 1 and Table 4. In Fig. 1, thiamin showed a retention time of 21 min. Raw peanuts contained $0.77 \pm 0.11$ and $0.81 \pm 0.01 \mathrm{mg} / 100 \mathrm{~g}$ of thiamin in the normal cultivars,

Table 2 Linearity, limit of detection (LOD), and limit of quantification (LOQ) of vitamin thiamin, riboflavin, and niacin by HPLC analyses

\begin{tabular}{llllcrr}
\hline Vitamins & Compounds & Calibration curve & $r^{2}$ & Linear range $(\mu \mathrm{g} / \mathrm{mL})$ & LOD $(\mu \mathrm{g} / \mathrm{mL})$ & $\mathrm{LOQ}(\mu \mathrm{g} / \mathrm{mL})$ \\
\hline Thiamin & Thiamin & $Y=41.81 x+0.87$ & 0.999 & $0.078-0.625$ & 0.038 & 0.115 \\
Riboflavin & FAD & $Y=47.01 x+0.08$ & 0.991 & $0.0178-0.1425$ & 0.004 & 0.013 \\
& FMN & $Y=413.53 x-5.24$ & 0.991 & $0.0166-0.1331$ & 0.001 & 0.001 \\
& Riboflavin & $Y=964.71 x-35.54$ & 0.996 & $0.1419-1.1350$ & 0.019 & 0.002 \\
Niacin & Nicotinic acid & $Y=40.36 x-0.14$ & 0.991 & $0.020-0.156$ & 0.008 & 0.056 \\
& Nicotinamide & $Y=32.95 x-0.46$ & 0.999 & $0.625-5.000$ & 0.025 & \\
\hline
\end{tabular}

FAD flavin adenine dinucleotide, FMN flavin mononucleotide

Table 3 Accuracy and repeatability precision (\%RSDr) for the analysis of thiamin, riboflavin, and niacin in standard reference materials (SRM 1849a and SRM 2387)

\begin{tabular}{lcccccc}
\hline Vitamins & \multicolumn{2}{c}{ Contents $(\mathrm{mg} / 100 \mathrm{~g})$} & & \% of certified value & \%RSDr & \\
\cline { 2 - 5 } & Certified value $^{\mathrm{a}}$ & Analytical value $^{\mathrm{b}}$ & Bias & & \\
\hline Thiamin (SRM 1849a) & $1.25 \pm 0.09$ & $1.32 \pm 0.12$ & 0.07 & 105.60 & 9.09 \\
Riboflavin (SRM 1849a) & $2.03 \pm 0.05$ & $1.94 \pm 0.07$ & 0.09 & 95.57 & 3.61 \\
Niacin (SRM 2387) & $10.80 \pm 1.00$ & $9.60 \pm 0.08$ & 1.20 & 88.89 & 1.80 \\
\hline
\end{tabular}

${ }^{\mathrm{a}}$ The certified reference values for the vitamin thiamin, riboflavin, and niacin in SRM 1849a and SRM 2387 were derived from the combination of results provided by NIST and collaborating laboratories

${ }^{\mathrm{b}}$ Values (mean $\pm \mathrm{SD}$ ) are based on five replicate analyses 
Fig. 1 Typical chromatograms of thiamin and niacin in standards (A), raw peanuts (B) and roasted peanuts $(\mathbf{C})$
(A)

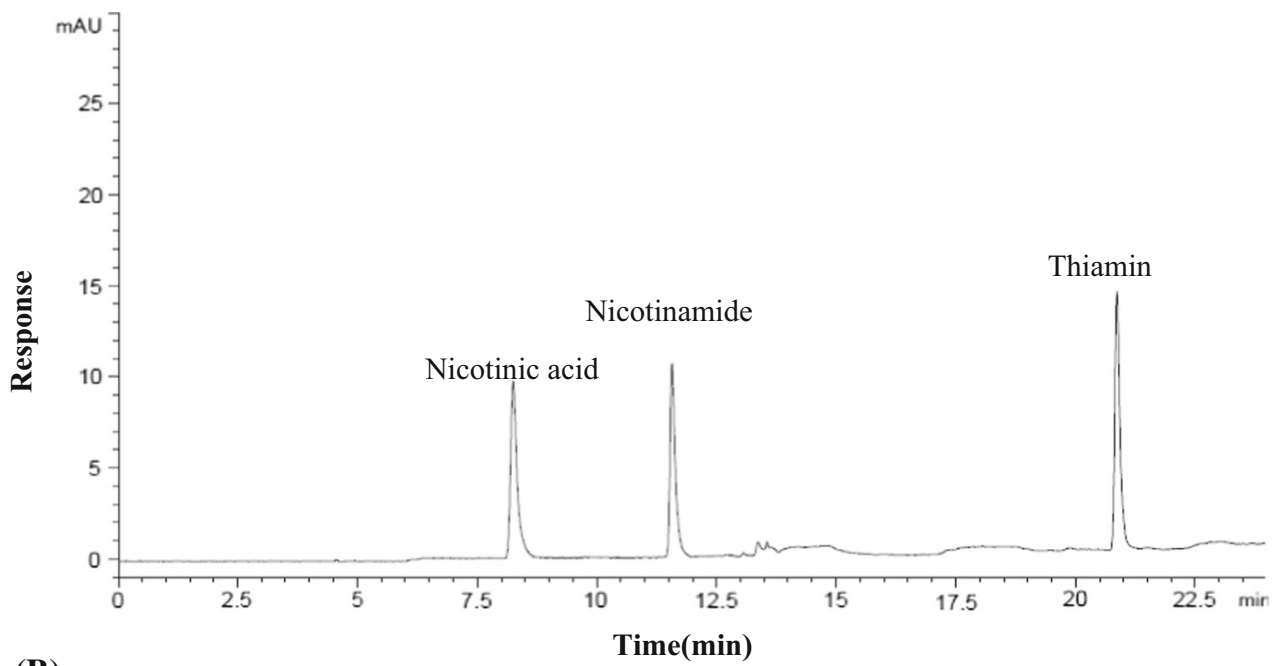

(B)
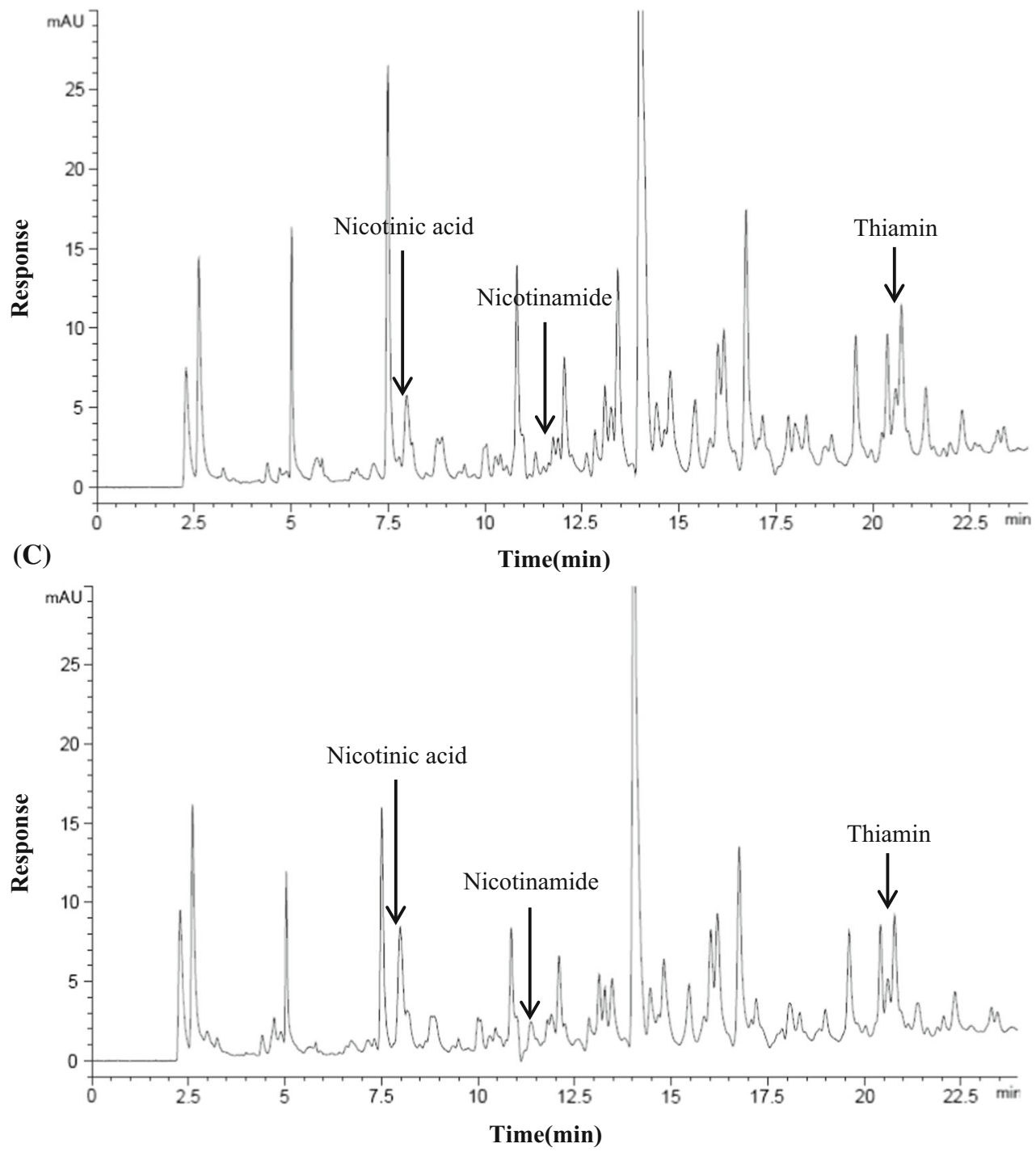
Table 4 Contents of thiamin in raw and roasted peanuts

\begin{tabular}{ll}
\hline Type & $\begin{array}{l}\text { Contents }(\mathrm{mg} / 100 \mathrm{~g}) \\
\text { Thiamin }\end{array}$ \\
\hline $\begin{array}{l}\text { Normal } \\
\text { Daekwang }\end{array}$ & \\
$\quad$ Raw & $0.81 \pm 0.01^{\mathrm{a}}$ \\
$\quad$ Roasted & $0.22 \pm 0.11^{\mathrm{b}}$ \\
Poongan & \\
Raw & $0.77 \pm 0.11^{\mathrm{a}}$ \\
$\quad$ Roasted & $0.55 \pm 0.08^{\mathrm{b}}$ \\
High-oleic & \\
K-Ol & \\
Raw & \\
Roasted & $0.99 \pm 0.02^{\mathrm{a}}$ \\
Milyang\#14 & $0.74 \pm 0.05^{\mathrm{b}}$ \\
Raw & \\
Roasted & $0.60 \pm 0.02^{\mathrm{b}}$ \\
\hline
\end{tabular}

Data were expressed as mean \pm standard deviation

Different letters $(\mathrm{a}, \mathrm{b})$ correspond a significant difference between raw and roasted peanuts within same cultivar $(P<0.05)$

whereas the high-oleic cultivars contained $0.60 \pm 0.02$ and $0.99 \pm 0.02 \mathrm{mg} / 100 \mathrm{~g}$ of thiamin, indicating no statistically significant difference in thiamin amounts between normal and high-oleic cultivars $(P>0.05)$. Comparing only two types of peanuts is, however, somewhat limited for elucidating significant differences between normal and high-oleic cultivars; therefore, studies need to consistently perform comparisons among the cultivars. Based on the USDA Nutrient Database Report [27] that reported $0.64 \mathrm{mg} / 100 \mathrm{~g}$ of thiamin in normal peanut cultivars, the cultivars analyzed in this study were confirmed to have higher amounts of thiamin than the reported value. Previous studies found that the amount of nutrients contained in peanuts can differ greatly due to extrinsic factors including cultivation period, location, and weather, as well as the type of cultivar [28-30]. After roasting, thiamin exhibited 27 and $71 \%$ retention rates in normal cultivars, while higholeic cultivars showed 74 and $146 \%$ retention rates, indicating a decrease in the amount of thiamin in 3 out of 4 samples. The USDA Nutrient Database Report [27] reported $0.15 \mathrm{mg} / 100 \mathrm{~g}$ of thiamin in roasted peanuts, which is calculated to be a $23 \%$ retention rate when compared with $0.64 \mathrm{mg} / 100 \mathrm{~g}$ of thiamin in raw peanuts. Thiamin is highly vulnerable to thermal treatment and is therefore known to have a low retention rate in general [16]. High temperature and prolonged duration of thermal treatment easily break molecular ring structures and methylene group chemical bonds in thiamin, leading to devitaminization [31]. Although thiamin is relatively stable at $100{ }^{\circ} \mathrm{C}$, its loss rate increases to $35 \%$ at the pasteurization temperature of $121{ }^{\circ} \mathrm{C}$. The loss rate induced by high temperature can be retained to a certain extent by structures in the food, such as stabilization through bonds with proteins [32]. Thiamin possesses a paramount acid resistance at $\mathrm{pH} 2.0-4.0$, with decreased stability in alkali conditions [31]. Additionally, thiamin loss in food not only occurs during cooking processes, but due to hot water during washing, and therefore, reduced hot water and cooking time will help increase the retention rates of thiamin [17].

\section{Riboflavin}

The amount of riboflavin in normal and high-oleic peanuts and changes in retention rate after roasting were examined. The results are shown in Fig. 2 and Table 5. In Fig. 2, FAD, FMN, and riboflavin were separated with retention times of 5.2, 8.1, and $15.2 \mathrm{~min}$, respectively. FAD was not detected in normal peanuts, and after roasting, 0.01, 0.02, and $0.02 \mathrm{mg} / 100 \mathrm{~g}$ of FAD were identified in Daekwang, $\mathrm{K}$-Ol, and Milyang\#14 cultivars, respectively. All normal and high-oleic peanut samples contained $0.01 \mathrm{mg} / 100 \mathrm{~g}$ of FMN, and Daekwang, Poongan, $\mathrm{K}-\mathrm{Ol}$, and Milyang\# 14 cultivars exhibited $0.05,0.06,0.12$, and $0.12 \mathrm{mg} / 100 \mathrm{~g}$ of FMN, respectively, after roasting. Riboflavin, on the other hand, was found in amounts of 0.02, 0.02, 0.05, and $0.02 \mathrm{mg} / 100 \mathrm{~g}$ in Daekwang, Poongan, $\mathrm{K}-\mathrm{Ol}$, and Milyang\#14 cultivars, respectively, but was reduced to $0.01,0.01,0.01$, and $0.00 \mathrm{mg} / 100 \mathrm{~g}$, respectively, after roasting. Thus, when considering all three forms together, roasting causes a two-sevenfold increase in the amount of riboflavin. Statistically significant differences were not observed in the amount of riboflavin between normal and high-oleic peanuts $(P>0.05)$, but significant differences were found between raw and roasted peanuts $(P<0.05)$. This increase in riboflavin after roasting was also seen in the USDA Nutrient Database Report [27], which reported 0.14 and $0.20 \mathrm{mg} / 100 \mathrm{~g}$ of riboflavin in raw peanuts and roasted peanuts, respectively. Riboflavin is stable to oxidation and thermal treatment; however, it is susceptible to destruction under alkaline conditions and exposure to visible and UV light [17]. Although riboflavin, as a strong oxidizing agent, easily reacts with radicals such as hydrogen ions, it is stable to external chemical energy and is reversibly reduced to dihydroriboflavin by a reducing agent [33]. Riboflavin also binds to proteins within foods, enabling the protection of prosthetic groups. Therefore, the relatively lower loss of riboflavin compared with thiamin in the results of this study can be explained by vitamin precursors that are converting into activated vitamins, thus increasing the measured amounts of riboflavin. In addition, increased amounts of riboflavin released from foods will 
Fig. 2 Typical chromatograms of riboflavin in standards (A), raw peanuts $(\mathbf{B})$ and roasted peanuts $(\mathbf{C})$

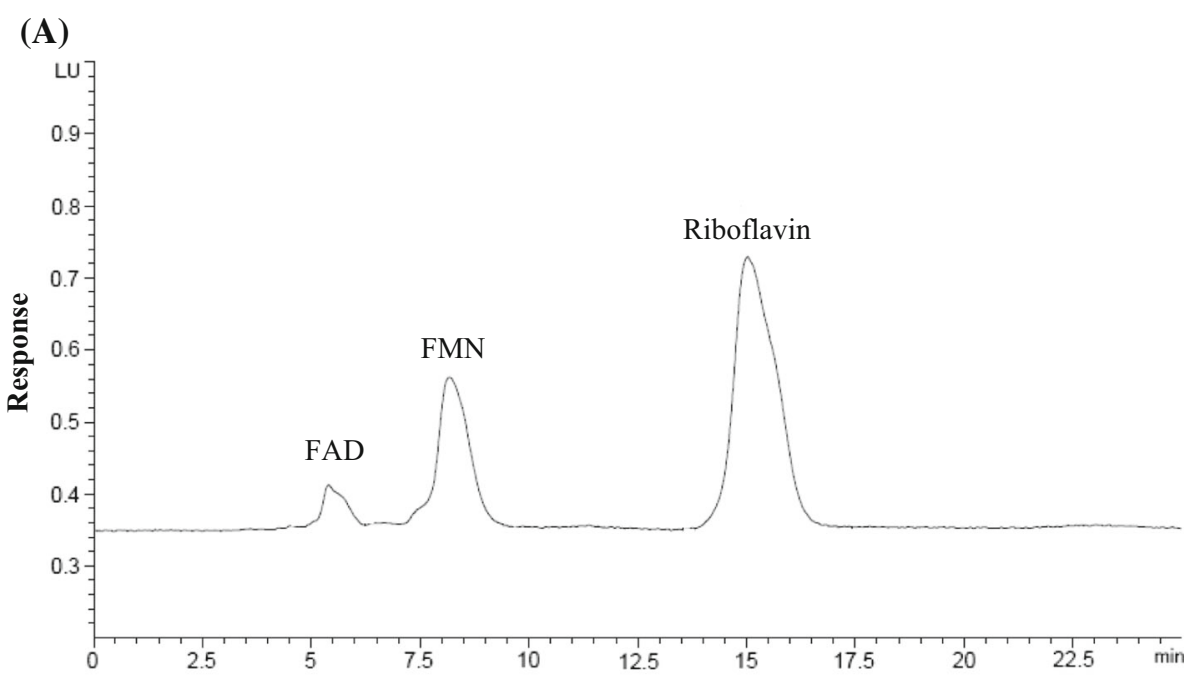

(B)

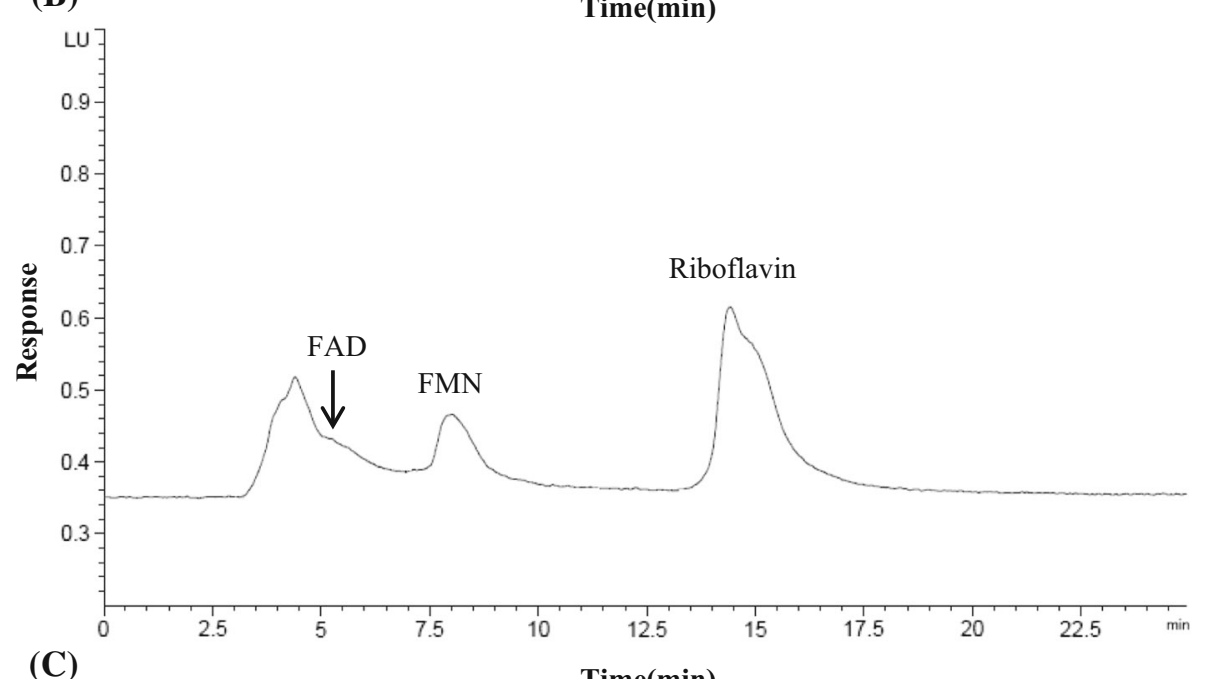

(C)

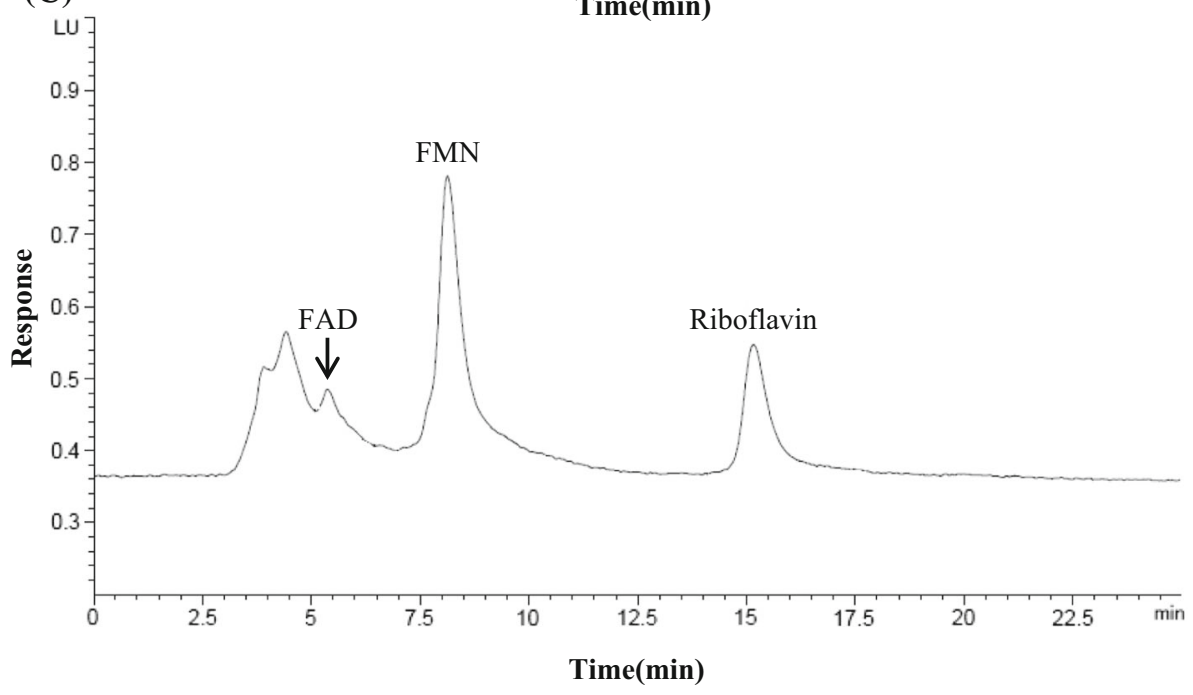

induce an increase in extraction efficiency and therefore may heighten the measured amount of riboflavin [34]. Lee et al. [12] found that riboflavin exerted superior heat- induced dissolution rates and sensitivity against humidity compared with other water-soluble vitamins. FMN and FAD are reported to be readily converted into riboflavin at 
Table 5 Contents of riboflavin in raw and roasted peanuts

\begin{tabular}{|c|c|c|c|c|c|}
\hline \multirow[t]{2}{*}{ Type } & \multicolumn{5}{|c|}{ Contents (mg/100 g) } \\
\hline & FAD & FMN & Riboflavin & Total riboflavin Eq. & Total riboflavin \\
\hline \multicolumn{6}{|l|}{ Normal } \\
\hline \multicolumn{6}{|l|}{ Daekwang } \\
\hline Raw & $0.00 \pm 0.00^{\mathrm{b}}$ & $0.01 \pm 0.00^{\mathrm{b}}$ & $0.02 \pm 0.00^{\mathrm{a}}$ & $0.03 \pm 0.00^{\mathrm{b}}$ & $0.03 \pm 0.00^{\mathrm{b}}$ \\
\hline Roasted & $0.01 \pm 0.00^{\mathrm{a}}$ & $0.05 \pm 0.01^{\mathrm{a}}$ & $0.01 \pm 0.00^{\mathrm{b}}$ & $0.06 \pm 0.01^{\mathrm{a}}$ & $0.07 \pm 0.01^{\mathrm{a}}$ \\
\hline \multicolumn{6}{|l|}{ Poongan } \\
\hline Raw & $0.00 \pm 0.00$ & $0.01 \pm 0.00^{\mathrm{b}}$ & $0.02 \pm 0.00^{\mathrm{a}}$ & $0.03 \pm 0.00^{\mathrm{b}}$ & $0.03 \pm 0.00^{\mathrm{b}}$ \\
\hline Roasted & $0.00 \pm 0.00$ & $0.06 \pm 0.01^{\mathrm{a}}$ & $0.01 \pm 0.00^{\mathrm{b}}$ & $0.06 \pm 0.01^{\mathrm{a}}$ & $0.07 \pm 0.01^{\mathrm{a}}$ \\
\hline \multicolumn{6}{|l|}{ High-oleic } \\
\hline \multicolumn{6}{|l|}{$\mathrm{K}-\mathrm{Ol}$} \\
\hline Raw & $0.00 \pm 0.00^{\mathrm{b}}$ & $0.01 \pm 0.00^{\mathrm{b}}$ & $0.05 \pm 0.01^{\mathrm{a}}$ & $0.06 \pm 0.00^{\mathrm{b}}$ & $0.06 \pm 0.00^{\mathrm{b}}$ \\
\hline Roasted & $0.02 \pm 0.01^{\mathrm{a}}$ & $0.12 \pm 0.01^{\mathrm{a}}$ & $0.01 \pm 0.00^{\mathrm{b}}$ & $0.11 \pm 0.01^{\mathrm{a}}$ & $0.15 \pm 0.01^{\mathrm{a}}$ \\
\hline \multicolumn{6}{|l|}{ Milyang\#14 } \\
\hline Raw & $0.00 \pm 0.00^{\mathrm{b}}$ & $0.01 \pm 0.00^{\mathrm{b}}$ & $0.02 \pm 0.00^{\mathrm{a}}$ & $0.02 \pm 0.00^{\mathrm{b}}$ & $0.02 \pm 0.00^{\mathrm{b}}$ \\
\hline Roasted & $0.02 \pm 0.01^{\mathrm{a}}$ & $0.12 \pm 0.01^{\mathrm{a}}$ & $0.01 \pm 0.00^{\mathrm{b}}$ & $0.10 \pm 0.01^{\mathrm{a}}$ & $0.14 \pm 0.01^{\mathrm{a}}$ \\
\hline
\end{tabular}

Data were expressed as mean \pm standard deviation. Different letters $(a, b)$ correspond a significant difference between raw and roasted peanuts within same cultivar $(P<0.05)$

$F A D$ flavin adenine dinucleotide, FMN flavin mononucleotide, Total riboflavin eq. Total riboflavin equivalent $=(\mathrm{FAD} \times 0.4537+\mathrm{FMN} \times 0.7869+$ riboflavin $)$
Table 6 Contents of vitamin niacin in raw and roasted peanuts

\begin{tabular}{llll}
\hline Type & \multicolumn{2}{l}{ Contents $(\mathrm{mg} / 100 \mathrm{~g})$} \\
\cline { 2 - 4 } & Nicotinic acid & Nicotinamide & Total niacin \\
\hline Normal & & & \\
Daekwang & & & \\
$\quad$ Raw & $0.33 \pm 0.02^{\mathrm{a} 1}$ & $0.28 \pm 0.02^{\mathrm{a}}$ & $0.61 \pm 0.04^{\mathrm{b}}$ \\
$\quad$ Roasted & $0.32 \pm 0.01^{\mathrm{a}}$ & $0.05 \pm 0.00^{\mathrm{b}}$ & $0.37 \pm 0.02^{\mathrm{a}}$ \\
Poongan & & & \\
Raw & $0.38 \pm 0.01^{\mathrm{b}}$ & $0.46 \pm 0.08^{\mathrm{a}}$ & $0.84 \pm 0.09^{\mathrm{a}}$ \\
$\quad$ Roasted & $0.47 \pm 0.01^{\mathrm{a}}$ & $0.40 \pm 0.06^{\mathrm{a}}$ & $0.87 \pm 0.07^{\mathrm{a}}$ \\
High-oleic & & & \\
K-Ol & & & \\
$\quad$ Raw & $0.78 \pm 0.02^{\mathrm{b}}$ & $0.44 \pm 0.02^{\mathrm{b}}$ & $1.22 \pm 0.04^{\mathrm{b}}$ \\
$\quad$ Roasted & $1.22 \pm 0.02^{\mathrm{a}}$ & $0.73 \pm 0.02^{\mathrm{a}}$ & $1.95 \pm 0.05^{\mathrm{a}}$ \\
Milyang\#14 & & & \\
$\quad$ Raw & $0.38 \pm 0.02^{\mathrm{b}}$ & $0.36 \pm 0.03^{\mathrm{b}}$ & $0.75 \pm 0.05^{\mathrm{b}}$ \\
Roasted & $0.77 \pm 0.03^{\mathrm{a}}$ & $0.69 \pm 0.09^{\mathrm{a}}$ & $1.46 \pm 0.12^{\mathrm{a}}$ \\
\hline
\end{tabular}

Data were expressed as mean \pm standard deviation

Different letters $(a, b)$ correspond a significant difference between raw and roasted peanuts within same cultivar $(P<0.05)$

acidic conditions, i.e., $\mathrm{pH}<5.0$ [35]. Although individuals often pay little attention to their intake of riboflavin owing to the mildness of the diseases caused by its deficiency compared with other vitamins, the deficiency of FMN and FAD, functional vitamins essential for lipid metabolism, lowers the oxidation of fatty acids, accumulates triacylglycerols in the liver, and decreases linoleic acid, linolenic acid, and arachidonic acid levels in serum and the liver, leading to similar side effects as those associated with the deficiency of essential fatty acids [36]. Another study found degenerated myelin of the central and peripheral nervous systems in riboflavin-deprived mice because of abnormal lipid metabolism that resulted from riboflavin deficiency. Hence, as riboflavin is involved in the metabolism of neurotransmitters, a fair amount of riboflavin needs to be ingested [37].

\section{Niacin}

The amount of niacin in normal and high-oleic peanuts and changes in the retention rate after roasting were examined. The results are shown in Fig. 1 and Table 6. In Fig. 1, nicotinic acid and nicotinamide were separated at retention times of 7.9 and $11.6 \mathrm{~min}$, respectively. Nicotinic acid amounts were not significantly different between normal and high-oleic peanuts $(P>0.05)$, while, except for the Daekwang cultivar, there were significant differences between the raw and roasted peanuts $(P<0.05)$. The increase was particularly higher in high-oleic peanuts than normal peanuts (from 0.78 to $1.22 \mathrm{mg} / 100 \mathrm{~g}$ for $\mathrm{K}$ - $\mathrm{Ol}$ and from 0.38 to $0.77 \mathrm{mg} / 100 \mathrm{~g}$ for Milyang\#14). Nicotinamide amounts decreased in normal peanuts after roasting (from 0.28 to $0.05 \mathrm{mg} / 100 \mathrm{~g}$ for Daekwang and from 0.46 to $0.40 \mathrm{mg} / 100 \mathrm{~g}$ for Poongan), and a significant increase 
in nicotinamide was observed after roasting high-oleic peanuts (from 0.44 to $0.73 \mathrm{mg} / 100 \mathrm{~g}$ for $\mathrm{K}$ - $\mathrm{Ol}$ and from 0.36 to $0.69 \mathrm{mg} / 100 \mathrm{~g}$ for Milyang\# 14$)(P<0.05)$. The total amount of vitamin $B$ significantly increased in all samples after roasting $(P<0.05)$, with the exception of Daekwang. The USDA Nutrient Database Report [27] noted $12.07 \mathrm{mg} / 100 \mathrm{~g}$ and $13.36 \mathrm{mg} / 100 \mathrm{~g}$ of niacin in raw peanuts and roasted peanuts, respectively. Niacin, a heterocyclic pyrimidine ring, has a highly stable structure and a high retention rate even when external energy is applied. Intermediate substances that release free radicals such as hydroxy radicals and hydrated electrons in foods are first oxidized with strong oxidizing agents such as riboflavin or other food components before reacting with niacin, resulting in extremely small niacin loss compared with other vitamins [38]. Niacinamide exists in free- or nucleotide-bound forms and is characterized as highly resistant to heat, light, acid, alkali, and oxidation. The studies on niacinamide therefore mainly utilized hydrolysis methods with acids and bases [39]. A study by Ahn [16] also reported that niacin had a high retention rate during cooking processes due to relatively low influences from thermal treatment, bleaching, and boiling in comparison with other water-soluble vitamins.

\section{Discussion}

This study investigated the amounts of thiamin, riboflavin, and niacin present in normal and high-oleic peanuts, and compared the retention rates of the vitamins after roasting. Method validation to analyze thiamin, riboflavin, and niacin using HPLC resulted in high linearity and superior LOD and LOQ compared with the literature. Accuracy and precision were confirmed by their conformation to the expected ranges of SRM. Riboflavin and niacin contents tend to increase with the roasting of raw peanuts, which is consistent with previous studies. Such an increase may be caused by heightened extraction efficiency from the thermal treatment of protein- or carbohydrate-bound vitamins in foods, rather than an increase in the amount of vitamin itself. This study is of significance in providing information on the amounts of water-soluble vitamins in varied peanut cultivars and basic data regarding changes in the amount of water-soluble vitamins after roasting processes.

Acknowledgments This research was supported by a Grant (17162MFDS082) from Ministry of Food and Drug Safety in 2018.

\section{References}

1. Woodroof JG (1983) Peanuts: production, processing, products, 3rd edn. AVI Pub. Co., Westport, pp 1-36
2. Norden AJ, Gorbet DW, Knauft DA, Young CT (1987) Variability in oil quality among peanut genotypes in the Florida breeding program. Peanut Sci 14:7-11

3. Bishi SK, Kumar L, Mahatma MK, Khatediya N, Chauhan SM, Misra JB (2015) Quality traits of Indian peanut cultivars and their utility as nutritional and functional food. Food Chem 176:107-114

4. Moore KM, Knauft DA (1989) The inheritance of high oleic acid in peanut. J Hered 80:252-253

5. Davis JP, Dean LO, Faircloth WH (2008) Physical and chemical characterizations of normal and high-oleic oils from nine commercial cultivars of peanut. J Am Oil Chem Soc 85:235-243

6. Knauft DA, Moore KM, Gorbet DW (1993) Further studies on the inheritance of fatty acid composition in peanut. Peanut Sci 20:74-76

7. Jung S, Swift D, Sengoku E, Patel M, Teulé F, Powell G, Moore K, Abbott A (2000) The high oleate trait in the cultivated peanut (Arachis hypogaea L.). I. Isolation and characterization of two genes encoding microsomal oleoyl-PC desaturases. Mol Gen Genet 263:796-805

8. Lopez Y, Nadaf HL, Smith OD, Connell JP, Reddy AS, Fritz AK (2000) Isolation and characterization of the $\Delta^{12}$-fatty acid desaturase in peanut (Arachis hypogaea L.) and search for polymorphisms for the high oleate trait in Spanish market-type lines. Theor Appl Genet 101:1131-1138

9. Patel M, Jung S, Moore K, Powel G, Ainsworth C, Abbott A (2004) High-oleate peanuts mutants result from a MITE insertion into the FAD2 gene. Theor Appl Genet 108:1492-1502

10. Lim HJ, Kim MS, Kim DS, Kim HS, Pae SB, Kim JK, Shin EC (2017) Comparison of lipid constituents and oxidative properties between normal and high-oleic peanuts grown in Korea. Korean J Food Sci Technol 49:235-241

11. Talcott ST, Passeretti S, Duncan CE, Gorbet DW (2005) Polyphenolic content and sensory properties of normal and high oleic acid peanuts. Food Chem 90:379-388

12. Lee JH, Kim SG, Lee DU, Park SJ, Lee JH, Lee KP, Kim DS, Choi SW, Baik MY (2005) Effects of temperature and relative humidity on water soluble vitamin contents in commercial vitamin tablet. Korean J Food Sci Technol 37:1028-1034

13. Kwak BM, Kim SH, Kim KS, Lee KW, Ahn JH, Jang CH (2006) Composition of vitamin $\mathrm{A}, \mathrm{E}, \mathrm{B}_{1}$ and $\mathrm{B}_{2}$ contents in Korean cow's raw milk in Korea. Korean J Food Sci Ani Resour 26:245-251

14. Ei-Hazmi MAF, Warsy AS (1987) Riboflavin status in a Saudi population: a study in Riyadh. Ann Nutr Metab 31:253-258

15. Jackson JA, Bums MJ (1974) Effects of cystine, niacin and taurine on cholesterol concentration in the Japanese quail with comments on bile acid metabolism. Comp Biochem Physiol A Comp Physiol 48:61-68

16. Ahn MS (1999) A study on the changes in physico-chemical properties of vegetables by Korean traditional cooking methods. Korean J Diet Cult 14:177-188

17. Chung HK, Yoon KS, Woo N (2016) Effects of cooking method on the vitamin and mineral contents in frequently used vegetables. Korean J Food Cook Sci 32:270-278

18. Andersen PC, Gorbet DW (2002) Influence of year and planting date on fatty acid chemistry of high oleic acid and normal peanut genotypes. J Agric Food Chem 50:1298-1305

19. Pattee HE, Isleib TG, Moore KM, Gorbet DW, Giesbrecht FG (2002) Effect of high-oleic trait and paste storage variables on sensory attribute stability of roasted peanuts. J Agric Food Chem 50:7366-7370

20. Isleib TG, Pattee HE, Sanders TH, Hendrix KW, Dean LO (2006) Compositional and sensory comparisons between normal- and high-oleic peanuts. J Agric Food Chem 54:1759-1763 
21. Lim HJ, Kim DS, Pan JH, Pae SB, Kim HS, Shin EC, Kim JK (2017) Characterization of physicochemical and sensory attributes of a novel high-oleic peanut oil cultivar (Arachis hypogaea ssp. Fastigiata L.). Appl Biol Chem 60:653-657

22. Kim GP, Lee J, Ahn KG, Hwang YS, Choi Y, Chun J, Chang WS, Choung MG (2014) Differential responses of B vitamins in black soybean seeds. Food Chem 153:101-108

23. MFDS (2011) Korea food code. Ministry of Food and Drug Safety, Chungbuk, pp 10173-10186

24. Kim SE, Kim JH, Lee SW, Lee MJ (2013) A study of roasting conditions on benzo $[a]$ pyrene content in coffee beans. J Korean Soc Food Sci Nutr 42:134-138

25. Albalá-Hurtado S, Veciana-Nogués MT, Izquierdo-Pulido M, Mariné-Font A (1997) Determination of water-soluble vitamins in infant milk by high-performance liquid chromatography. J Chromatogr A 778:247-253

26. Kim SH, Kim JH, Lee HJ, Oh JM, Lee SH, Bahn KN, Seo IW, Lee YJ, Lee JH, Kang TS (2015) Simultaneous determination of water soluble vitamin B group in health functional foods ets by HPLC. J Food Hyg Saf 30:143-149

27. USDA (2018) United States Department of Agriculture National Nutrient Database for Standard Reference, Release 28. Web. http://www.nal.usda.gov. Accessed at 01 April 2018

28. Shin EC, Pegg RB, Phillips RD, Eitenmiller RR (2010) Commercial peanut (Arachis hypogaea L.) cultivars in the United States: phytosterol composition. J Agric Food Chem 58:9137-9146

29. Shin EC, Craft BD, Pegg RD, Eitenmiller RR (2010) Chemometric approach to fatty acid profiles in Runner-type peanut cultivars by principal component analysis (PCA). Food Chem 118:1262-1270
30. Shin EC, Huang YZ, Pegg RB, Phillips RD, Eitenmiller RR (2009) Commercial runner peanut cultivars in the United States: tocopherol composition. J Agric Food Chem 57:10289-10295

31. Dwivedi BK, Arnold RG (1973) Chemistry of thiamin degradation in food products and model systems. Rev J Agric Food Chem 21:54-60

32. Hur JY, Hwang IK (2002) The stability of water-soluble and fatsoluble vitamins in milk by heat treatments. Korean J Soc Food Cook Sci 18:487-494

33. Fujimake M, Morita M (1968) Radiation chemistry of foods. I. Reaction rate constants of some foods constituents with hydrated electrons and hydroxyl radical. Agric Biol Chem 32:574-579

34. Fox JB, Thayer DW, Jenkins EK, Philips JG, Ackerman SA, Beecher GR, Holden JM, Morrow FD, Quirbach DM (1989) Effect of gamma irradiation on the B vitamin of pork chops and chicken breasts. Int J Radiat Biol 55:689-703

35. Russel LF, Vanderslice JT (1990) A comprehensive review of vitamin $\mathrm{B}_{2}$ analytical methodology. J Micronutr Anal 8:257-310

36. Hoppel C, Dimarco JP, Tandler B (1979) Riboflavin and rat hepatic cell structure and function, mitocondrial oxidative metabolism in deficiency states. J Biol Chem 254:4164-4170

37. Shaw JH, Phillips PH (1941) The pathology of riboflavin deficiency in the rat. J Nutr 22:345-358

38. Bruhlmann U, Hayon E (1974) One-electron redox reaction of water soluble vitamins. I. Nicotinamide (vitamin $\mathrm{B}_{5}$ ) and related compounds. J Am Chem Soc 96:6169-6175

39. Kim HS, Jang DK, Woo DK, Woo KL (2002) Comparison of preparation methods for water soluble vitamin analysis in foods by reversed-phase high performance liquid chromatography. Korean J Food Sci Technol 34:141-150 